\title{
THE PHYTOLITH ${ }^{14} \mathrm{C}$ PUZZLE: A TALE OF BACKGROUND DETERMINATIONS AND ACCURACY TESTS
}

\author{
Guaciara M Santos ${ }^{1,2} \bullet$ Anne Alexandre ${ }^{3} \cdot$ Heloisa H G Coe $^{4} \cdot$ Paul E Reyerson $^{5} \bullet$ John R Southon ${ }^{1} \bullet$ \\ Cacilda N De Carvalho ${ }^{6}$
}

ABSTRACT. Over the past decades, analysis of occluded carbon in phytoliths (opaline silica mineral bodies that form in and between plant cells) has become a workhorse of paleoclimate and archaeological studies. Since different plant types exhibit distinctive phytolith morphologies, their assemblages are used in identifying vegetation histories or food culture adaptations. A few direct radiocarbon AMS measurements of phytoliths have been carried out, but these measurements are difficult due to the low concentrations of phytoliths in some plant species, and the small amount of $\mathrm{C}$ per phytolith $(<2 \%)$. In addition, no phytoliths samples of a known ${ }^{14} \mathrm{C}$ age are available to verify measurement accuracy and precision, and to check sample preparation protocols. Background corrections are also difficult to address due to the lack of suitable material. In this work, we designed a procedure to quantify a suitable blank using $\mathrm{SiO}_{2}$ powder samples (close to the opal structure, and free of ${ }^{14} \mathrm{C}$ ). The full phytolith extraction showed high carbon contamination components: a) $\sim 3 \mu \mathrm{g}$ of modern $\mathrm{C}$ and $\sim 2 \mu \mathrm{g}$ of dead C. We also performed accuracy tests on large phytolith-occluded carbon samples extracted from soils and harvested plants. The unexpected ${ }^{14} \mathrm{C}$ ages in some of the results triggered further investigations of possible sources of carbon contamination.

\section{INTRODUCTION}

A phytolith is a rigid, microscopic $(<60-100 \mu \mathrm{m})$, highly microporous amorphous silica particle that forms in many living higher plants. Soluble silicon in the soil water is absorbed by the plant roots. As water passes through plant cells during metabolism, opaline silica (phytoliths) is deposited along cell walls or filling the cell lumen and the intercellular spaces (Sangster et al. 2009). The silica deposits account for a few ppm to $15 \%$ dry weight (Webb and Longstaffe 2002; Piperno 2006; Blecker et al. 2006). With plant decay, phytoliths (well preserved in oxidizing environments) are either incorporated into soils or exported via regional watersheds and sediments. Through the morphological identification of phytolith types, modern phytolith assemblages from soil tops have been calibrated as a proxy of present vegetation parameters (Bremond et al. 2005a,b, 2008a,b; Albert et al. 2006; Lu et al. 2006). Fossil phytolith assemblages are used in reconstructing either paleovegetation and related climate parameters (e.g. Prasad et al. 2005) or food culture adaptations in the archaeological context (Piperno 2006).

Phytoliths can occlude small amounts of a broad range of other elements (N, Fe, Al, etc.), including carbon. Occluded $\mathrm{C}$, trapped during phytolith formation, represents less than $2 \%$ of the phytolith weight (Pironon et al. 2001). Stable carbon isotopic analyses $\left(\delta^{13} \mathrm{C}\right)$ of these carbon macromolecules suggested the presence of lipids and sugars or proteins, assumed to originate from the photosynthesized cell walls or cell lumen of the plant (Wilding et al. 1967; Smith and Anderson 2001; Elbaum et al. 2009). Other carbon isotopic studies have investigated the potential of phytolith-occluded C for providing information on the photosynthetic pathway of the vegetation sources (Kelly et al. 1991; Smith and White 2004; Carter 2009).

Despite the low $\mathrm{C}$ content, direct radiocarbon dating of opal phytoliths is immediately attractive because the $\mathrm{C}$ occluded in the silica body is fully protected from oxidizing environments. A few

\footnotetext{
${ }^{1}$ Earth System Science, University of California, Irvine, B321 Croul Hall, Irvine, California 92697-3100, USA.

${ }^{2}$ Corresponding author. Email: gdossant@uci.edu.

${ }^{3}$ CEREGE, CNRS, UPCAM-III, Europôle méditerranéen de l'Arbois BP 80, 13545, Aix en Provence cedex 04, France.

${ }^{4}$ Lagemar, Inst. de Geociências, Universidade Federal Fluminense, Niteroi RJ, Brazil.

${ }^{5}$ Depart. of Geography, University of Wisconsin-Madison, 550 North Park Street, Madison, Wisconsin 53706, USA.

${ }^{6}$ Depart. de Geoquimica, Inst. de Química, Universidade Federal Fluminense, Niteroi RJ, Brazil.
} 
direct ${ }^{14} \mathrm{C}$ AMS measurements of phytolith carbon have been carried out, in attempts to obtain absolute chronologies (Kelly et al. 1991; Mulholland and Prior 1993; McClaran and Umlauf 2000; Piperno and Stothert 2003; Piperno 2006).

Kelly et al. (1991) were the first to explore the use of carbon isotope studies on phytoliths for paleoenvironmental reconstruction. Although the focus of their paper was on stable isotopic characterization of the $\mathrm{C}$ occluded within phytoliths (as a tool to differentiate between phytoliths produced from $\mathrm{C}_{3}$ and $\mathrm{C}_{4}$ grasses from temperate regions of North America), 6 of the ${ }^{14} \mathrm{C}$ ages they obtained were chronologically inverted (i.e. ${ }^{14} \mathrm{C}$ ages were younger at depth and older towards the surface). Kelly et al. clearly recognized the importance of these inversions and devoted much of the latter half of their paper to attempting to explain them. They concluded that phytoliths are subject to extensive reworking or mixing processes that seriously disturb the stratigraphic record.

McClaran and Umlauf (2000) reported ${ }^{14} \mathrm{C}$ results on soil organic matter (SOM) and phytolithoccluded $\mathrm{C}$ from desert grassland. Overall ${ }^{14} \mathrm{C}$ results from phytolith carbon were much older than from SOM samples. In addition, the ${ }^{14} \mathrm{C}$ age of the $\mathrm{SOM}$ pool from the top $2 \mathrm{~cm}$ gave a post-bomb result (i.e. the sample contained excess ${ }^{14} \mathrm{C}$ from thermonuclear weapons testing, carried out during the late 1950s and early 1960s), while phytoliths from the same layer dated back to $\sim 800 \mathrm{yr}$ BP. Although they expected the $\mathrm{SOM}{ }^{14} \mathrm{C}$ results to be younger throughout the soil column, due to downward percolation of young humic acids in groundwater, no explanation was provided for the remarkably old age obtained from the topsoil phytolith carbon sample. Furthermore, they had shortened the $30 \% \mathrm{H}_{2} \mathrm{O}_{2}$ bath (designed to remove organic matter) from 4-6 hr to $30 \mathrm{~min}$; therefore, they expected that the phytolith samples might still be contaminated by residual younger ${ }^{14} \mathrm{C}$ organic matter. If that was the case, the "non-contaminated" ${ }^{14} \mathrm{C}$ ages from their phytolith carbon samples (if properly processed) might have been even older.

Piperno and collaborators, mostly focusing on human exploitation and domestication of plants have reported several results on directly ${ }^{14} \mathrm{C}$ measurements of phytolith-occluded $\mathrm{C}$ (Piperno and Pearsall 1993; Zhao and Piperno 2000; Piperno and Stothert 2003; Piperno 2006). In Piperno and Stothert (2003), for example, one of the ${ }^{14} \mathrm{C}$ values was matched with dates obtained on charcoal and shells. The ${ }^{14} \mathrm{C}$ AMS results from the smallest samples were obtained by an AMS method that involves dilution of a relatively small $\mathrm{CO}_{2}$ sample $(<0.250 \mathrm{mg} \mathrm{C}$ after combustion) with a known quantity of ${ }^{14} \mathrm{C}$-dead $\mathrm{CO}_{2}$ to ensure that final graphite target sizes were in the accepted measuring range $(0.5$ to $1 \mathrm{mg} \mathrm{C}$ ). To establish if the microsample-AMS dilution method could work (i.e. to show they could increase the $\mathrm{CO}_{2}$ sample pool after combustion without affecting the final ${ }^{14} \mathrm{C}$ result), tests were performed using a known ${ }^{14} \mathrm{C}$-age sample (TIRI-B Belfast pine wood with a consensus age of $4503 \pm 6$ yr BP). However, no phytolith or similar material was processed and measured to check phytolith extraction protocols.

Carbon isotope results from modern phytolith assemblages (harvested plants or topsoils in paleoclimatic reconstructions), usually involve only stable isotope measurements due to the small amount of $\mathrm{CO}_{2}$ recovered from each sample (Smith and White 2004; Carter 2009). Consequently, the chronology associated with phytoliths is generally obtained by ${ }^{14} \mathrm{C}$ AMS or independent dating techniques on different materials, or they are simply assumed to be "modern" (when samples are from topsoil or living plants). The only post-bomb ${ }^{14} \mathrm{C}$ dating of phytolith carbon that we can find was published by Piperno and Becker (1996). The phytolith assemblage came from a soil depth of 0-20 $\mathrm{cm}$ from a tropical forest floor, and the processed phytolith material (presumably chemically extracted by Piperno and Becker) was combusted and graphitized at University of California, Riverside, and measured at CAMS/Livermore. As far we are aware, this result is the only evidence that "modern" phytolith assemblages are in fact valid indicators of present-day ${ }^{14} \mathrm{CO}_{2}$ atmospheric conditions. 
More recent attempts to match ${ }^{14} \mathrm{C}$ date phytoliths with independent chronologies have demonstrated to be particularly difficult (Prior et al. 2005; Rieser et al. 2007). In these studies, dating specialists have tried to match ${ }^{14} \mathrm{C}$ ages of phytolith carbon with optically stimulated luminescence (OSL) dates (also from phytoliths) and tephrochronology information. C A Prior (personal communication, 2005) believed that their difficulties in matching these chronologies are mostly associated with the phytolith sample extraction methods applied for the samples undergoing ${ }^{14} \mathrm{C}$ dating.

Today, ${ }^{14} \mathrm{C}$ AMS can easily measure targets of $0.020 \mathrm{mg} \mathrm{C}$ (Santos et al. 2007b), reducing the required amount of organic material to be processed for a measurement. However, the phytolith extraction background or procedural blank is still difficult to quantify due to the lack of a suitable blank material. Since graphite targets produced are in the sub-mg range, sources of C contamination must be addressed carefully (Santos et al. 2007a). Furthermore, no phytoliths of known age are available to verify measurement accuracy and precision, or to check sample preparation protocols. The combination of an appropriate background assessment and a known-age phytolith standard are essential for quantifying realistic uncertainties associated with sample preparation and ${ }^{14} \mathrm{C}$ measurements, leading to a better interpretation of the scientific evidence. Note that none of the previous phytolith ${ }^{14} \mathrm{C}$ studies (mentioned above) have undertaken a full suite of ${ }^{14} \mathrm{C}$ measurements on blanks or phytolith secondary standards to directly evaluate extraction protocols.

With the purpose of quantifying a procedural blank and performing accuracy tests, we measured ${ }^{14} \mathrm{C}$-free $\mathrm{SiO}_{2}$ powder (as a first attempt to mimic the opal structure), and conducted multiple measurements of large amounts of phytoliths extracted from soils and harvested plants. The unexpected age and variability of some of the results obtained on this work triggered further evaluation of phytolith extraction procedures and investigations of possible sources of $\mathrm{C}$ contamination. These extra studies included ${ }^{14} \mathrm{C}$ measurements of phytoliths extracted from living plants obtained from 3 locations of the bulk plant material itself, of $\mathrm{CO}_{2}$ from lab air (CEREGE and KCCAMS) and plant sampling site air and of solvents (methanol and ethanol — to determine sources of carbon) and dry ice used in laboratory procedures.

\section{MATERIALS AND METHODS}

\section{Phytolith Samples}

Two phytolith samples from CEREGE (France) that were available in large amounts, previously chemically treated for environmental calibration (Kandara; Bremond et al. 2005) or used as oxygen isotope laboratory standard due to its homogeneity (MSG70; Crespin et al. 2008), were selected to check reproducibility and accuracy.

The MSG70 sample originates from the Mascareignite level $(10-20 \mathrm{~cm})$ of a volcanoclastic soil from La Reunion (France). The morphological study suggests that phytoliths extracted are mostly from bamboo plants (Meunier et al. 1999). Two ${ }^{14} \mathrm{C}$ dates from charcoals that set the boundaries for this level were obtained by NSF-Arizona AMS Laboratory; they are $335 \pm 90{ }^{14} \mathrm{C}$ yr for charcoals from the upper part $(7.5-10 \mathrm{~cm})$ of the mascareignite horizon and $3820 \pm 85{ }^{14} \mathrm{C}$ yr for charcoals from the lower and main part $(10->20 \mathrm{~cm})$ of the horizon (Ouar 1998).

The Kandara sample (Kandara $0-1-2-4$; Bremond et al. 2005a) is a mixture of 4 samples collected along a forest/savanna transect (Cameroon, West Africa) from the top of an hydromorphic soil on the shoreline of a swamp (samples 0 and 1) and a ferralitic soil (samples 2 and 4 ). The phytoliths are mainly from palms and dicotyledon trees. This sample is assumed to be "modern" (decades or a few hundred years old) as the phytolith assemblage reflects the current vegetation assemblage (Bremond et al. 2005a). 
Three phytolith samples were extracted from living grasses for the purpose of this study: a) the Grass1 sample obtained from leaves and stems of grasses harvested in 2007 from the side of a crop field on a calcisol, close to the CEREGE laboratory, Aix-en-Provence, France; b) the BioCore Prairie obtained from leaves and stems of grasses harvested in 2008 from a rural area in Madison, Wisconsin, USA. This grass was growing on about $30 \mathrm{~cm}$ of loess terrain, underlain by glacial till; and c) the MN sample, also extracted from leaves and stems of grasses picked in 2008 from a rural area in Minnesota, USA, underlain by till or outwash.

Bulk fractions from the living grasses and several other materials were also selected for this study. The complete sample list and its rationale are shown in Table 1, and will be discussed further below.

Phytolith samples for ${ }^{14} \mathrm{C}$ AMS measurements were subjected to the following steps: a) phytolith extraction followed by surface organic matter removal (details below), and b) combustion and graphitization (AMS target preparation).

\section{Phytolith Extraction}

Phytoliths were extracted from dry soil following the summarized protocol adapted from Kelly (1990): (a) 20 g of soil was slightly crushed and sieved at $2 \mathrm{~mm}$; (b) carbonates were dissolved using $\mathrm{HCl}(1 \mathrm{~N})$; (c) iron oxides were reduced with $88.4 \mathrm{~g} / \mathrm{L}$ of trisodium citrate $\left(\mathrm{C}_{6} \mathrm{H}_{5} \mathrm{Na}_{3} \mathrm{O}_{7}\right)$ and $1 \mathrm{~g} / \mathrm{L}$ of sodium dithionite $\left(\mathrm{Na}_{2} \mathrm{O}_{4} \mathrm{~S}_{2}\right)$ in $\mathrm{H}_{2} \mathrm{O}$; (d) organic matter was oxidized using $\mathrm{H}_{2} \mathrm{O}_{2}(30 \%)$ until the reaction subsided; followed by (e) deflocculation in a sodium hexametaphosphate $\mathrm{Na}\left(\mathrm{PO}_{3}\right)_{6}(5 \%)$ solution buffered at $\mathrm{pH} 7$; (f) sieving of the samples at $60 \mu \mathrm{m}$; and (g) clay removal by sedimentation or centrifugation. Densimetric separation (h) of phytoliths was carried out using a zinc bromide heavy liquid $\left(\mathrm{ZnBr}_{2}\right)$ with a density of 2.3; (i) the supernatant (phytoliths) was washed with $\mathrm{HCl}(1 \mathrm{~N})$ and distilled water, using hydrophobic fluoropore filters (PTFE filters) built in a glass filtration unit. Phytoliths were removed from the filters using a flux of distilled water. The PTFE filters (\#1.2 to $2 \mu \mathrm{m}$ ) were moistened with a few drops of ethanol before filtration (as recommended by the vendor). The phytoliths retained were then washed with $\mathrm{HCl}$ and distilled water; and (j) finally, phytolith samples were transferred to glass vials and dried in an oven at $110{ }^{\circ} \mathrm{C}$ for at least $24 \mathrm{hr}$.

Steps (b) to (e) were performed in polypropylene centrifuging bottles. Between each step, the sample was rinsed with distilled water spiked with a few drops of $\mathrm{CaCl}_{2}$ (to help phytoliths aggregate and sink). The supernatant was discarded after centrifugation.

Phytoliths were extracted from living grasses using the steps described below: (a) leaves and stems were broken down to small pieces and dried at $105^{\circ} \mathrm{C}$ for $36 \mathrm{hr}$ after having been immersed in a bath of $10 \% \mathrm{HCl}$; (b) organic matter was digested by $\mathrm{H}_{2} \mathrm{SO}_{4}$ heated in a water bath at $80{ }^{\circ} \mathrm{C}$ for periods of 2-6 hr. The procedure was repeated at least 3 times or until all plant material dissolved; (c) samples were immersed in $\mathrm{H}_{2} \mathrm{O}_{2}(30 \%)$, stirred, and returned to the water bath at $80^{\circ} \mathrm{C}$. The procedure was repeated until the sample was completely transparent; (d) to assure that samples were totally free of any organic matter, phytolith samples were rinsed (CEREGE) or immersed and heated at $80{ }^{\circ} \mathrm{C}$ (UW-Madison) with equal amounts of $8 \% \mathrm{HClO}_{4}$ and $\mathrm{HNO}_{3}$ at least 3-4 times; (d) finally, samples were transferred to glass vials and allowed to dry overnight at $110^{\circ} \mathrm{C}$. Between each step, the centrifuged/diluted/decanted sample was rinsed with distilled water. For this procedure, Pyrex ${ }^{\circledR}$ beakers and glass vials (for storage) were solely used.

After extraction, the purity of all samples extracted at CEREGE was checked by observing aliquots of phytoliths mounted on slides under an optical microscope (X600). For the samples extracted at 
Table 1 The sample list and its rationale.

\begin{tabular}{|c|c|c|}
\hline Goal & Sample & Description \\
\hline \multirow[t]{3}{*}{$\begin{array}{l}\text { Background } \\
\text { assessment }\end{array}$} & $\begin{array}{l}\mathrm{SiO}_{2} \text { powder } \\
\text { (Aldrich,-325 mesh): }\end{array}$ & $\begin{array}{l}\text { Subjected to phytolith extraction procedure to quan- } \\
\text { tify chemical extraction background. }\end{array}$ \\
\hline & $\begin{array}{l}\text { Coal (POC\#3-Ar- } \\
\text { gonne Premium coal) } \\
\text { A/B/A pretreated: }\end{array}$ & $\begin{array}{l}\text { Used as blank to determinate the modern } \mathrm{C} \text { contami- } \\
\text { nation component (MC) for: a) combustion and } \\
\text { graphitization background procedures, and b) phy- } \\
\text { tolith extraction procedure (by spiking } \mathrm{SiO}_{2} \text { powder). }\end{array}$ \\
\hline & OX-I (oxalic acid I): & $\begin{array}{l}\text { Used as blank to determinate the dead C contamina- } \\
\text { tion component (DC) for: a) combustion and graphi- } \\
\text { tization background procedures, and b) phytolith } \\
\text { extraction procedure (by spiking } \mathrm{SiO}_{2} \text { powder). In ad- } \\
\text { dition of normalization of samples. }\end{array}$ \\
\hline \multirow[t]{2}{*}{ Accuracy tests } & MSG70: & $\begin{array}{l}\text { Phytolith extracted at CEREGE from the Mascareig- } \\
\text { nite level }(10-20 \mathrm{~cm}) \text { of a volcanoclastic soils from } \\
\text { La Reunion (France) (Meunier et al. } 1999) \text {. The phy- } \\
\text { tolith layer accumulated between } 335 \pm 90 \text { and } \\
3845 \pm 85 \mathrm{yr} \text { BP }\left({ }^{14} \mathrm{C} \text { from charcoal samples). }\right.\end{array}$ \\
\hline & KANDARA: & $\begin{array}{l}\text { Phytoliths extracted at CEREGE from the humic ho- } \\
\text { rizon of a feralitic soil of a forest/savanna transect } \\
\text { from Kandara, Cameroon collected in } 1997 \text { (it was } \\
\text { thought to be modern, as the phytolith assemblage re- } \\
\text { flects the current vegetation-Bremond et al. 2005a). }\end{array}$ \\
\hline \multirow{5}{*}{$\begin{array}{l}\text { Source of } \\
\text { contamination } \\
\text { assessment }\end{array}$} & $\begin{array}{l}\text { Grass1 (bulk grass } \\
\text { and phytoliths): }\end{array}$ & $\begin{array}{l}\text { Leaves and stems of grasses harvested in } 2007 \text { from a } \\
\text { crop field close to the CEREGE laboratory, France. }\end{array}$ \\
\hline & $\begin{array}{l}\text { MN (bulk grass and } \\
\text { phytoliths): }\end{array}$ & $\begin{array}{l}\text { Leaves of grasses harvested in } 2008 \text { from a rural area } \\
\text { in Minnesota, USA. Phytoliths extracted at UW-Mad- } \\
\text { ison, USA. }\end{array}$ \\
\hline & $\begin{array}{l}\text { BioCore Prairie (bulk } \\
\text { grass and phytoliths): }\end{array}$ & $\begin{array}{l}\text { Leaves of grasses harvested in } 2008 \text { from a nature pre- } \\
\text { serve in Madison, Wisconsin, USA. Phytoliths ex- } \\
\text { tracted at UW-Madison, USA. }\end{array}$ \\
\hline & $\begin{array}{l}\mathrm{CO}_{2} \text { extracted from } \\
\text { air samples: }\end{array}$ & $\begin{array}{l}\text { From rural areas (Madison and Minnesota), CEREGE } \\
\text { and UCI processing labs. }\end{array}$ \\
\hline & Dry ice: & Used at the KCCAMS/UCI prep laboratory. \\
\hline
\end{tabular}

the UW-Madison (BioCore Prairie and MN, see Tables 1, 2), we deliberately decided to skip the purity evaluation to avoid removing some of the material and consequently reducing the graphite target sizes. Previous phytolith samples extracted at the UW-Madison laboratory, following the procedure described above, were mounted on slides and checked under the microscope and considered clean of surface contamination. 
118

G M Santos et al.

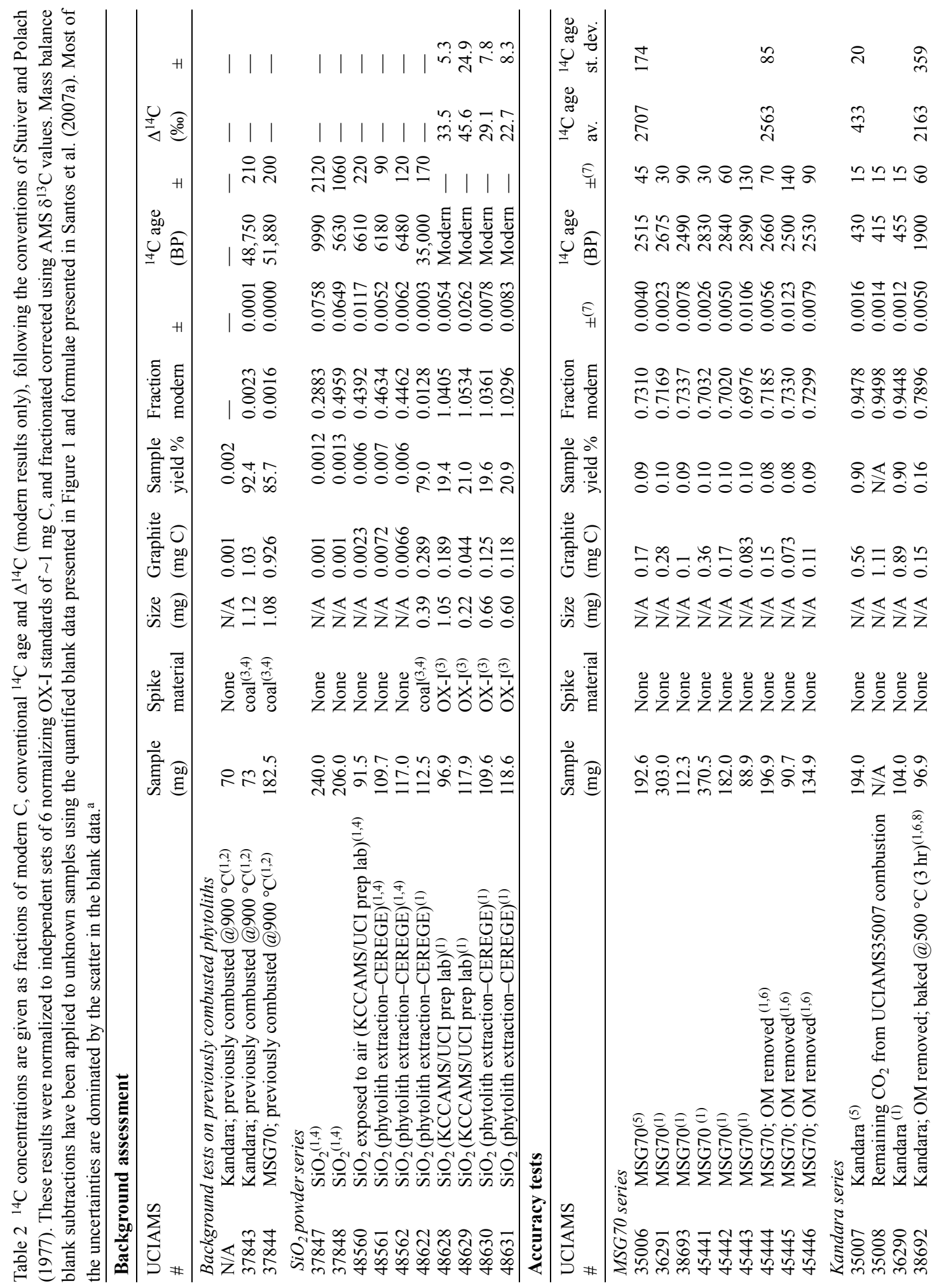




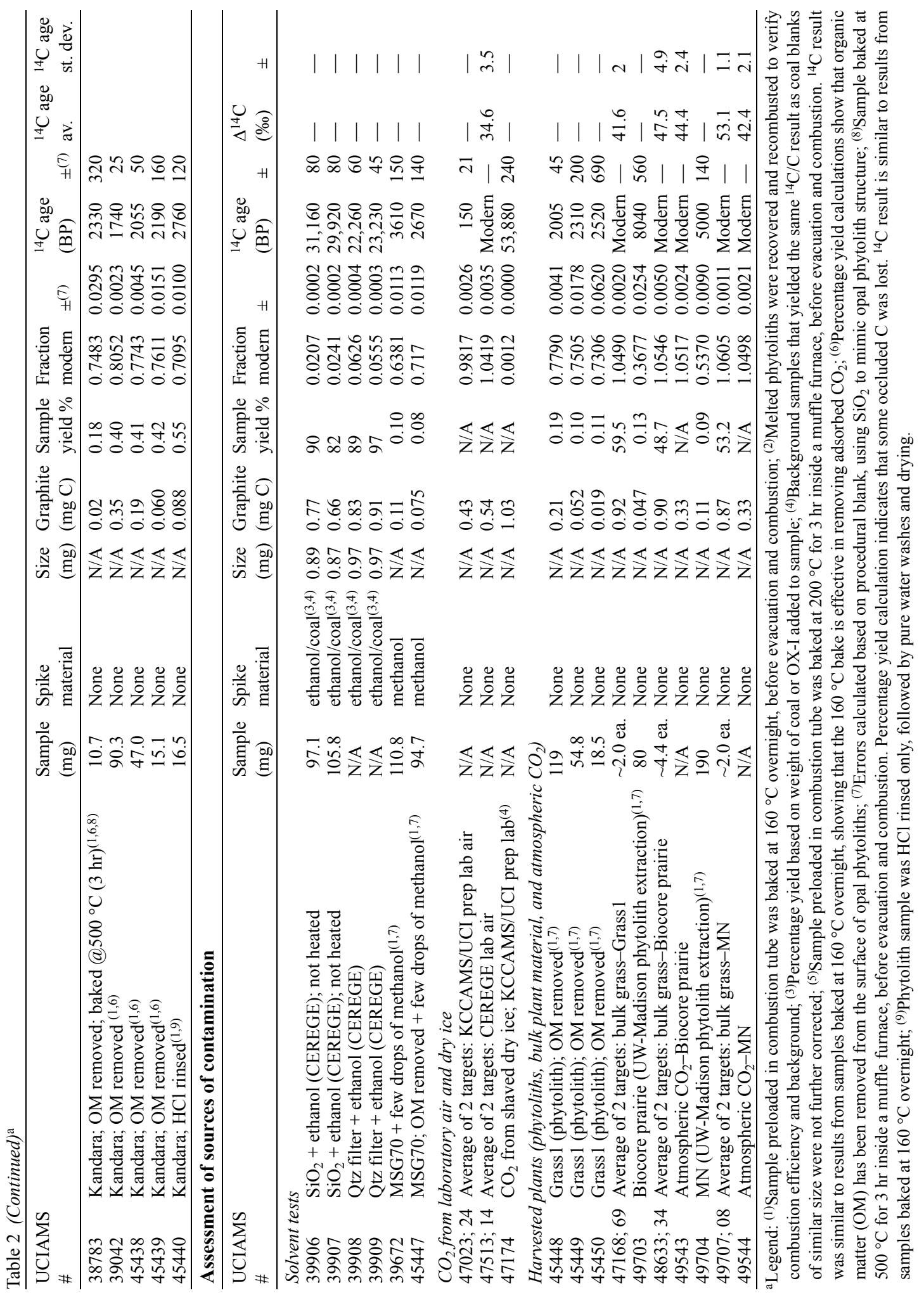




\section{${ }^{14} \mathrm{C}$ AMS Target Preparation and Measurement}

To obtain graphite targets from organic carbon, chemically pretreated material must undergo combustion at $900{ }^{\circ} \mathrm{C}$ in an evacuated, sealed 6-mm OD quartz tube (prebaked at $900{ }^{\circ} \mathrm{C}$ for $3 \mathrm{hr}$ ) in the presence of prebaked cupric oxide ( $\sim 80 \mathrm{mg}$ ) and silver wire ( $3 \mathrm{~mm}$ long $\times 1 \mathrm{~mm}$ thick). After combustion, the $\mathrm{CO}_{2}$ samples are individually released inside a vacuum line, cryogenically cleaned, and reduced to graphite, using hydrogen at $550{ }^{\circ} \mathrm{C}$ over prebaked iron powder (Santos et al. 2004, 2007a,b).

The $\mathrm{SiO}_{2}$ powder (used for background assessment — see below), and the phytolith samples themselves, were prebaked at $160{ }^{\circ} \mathrm{C}$ overnight before evacuation for combustion, and were attached warm to the vacuum line to avoid "boiling" of the powder under vacuum due to the release of large volumes of gasses adsorbed on these fine powders. This procedure helped us reduce the backgrounds from adsorbed $\mathrm{CO}_{2}$, as well as to minimize samples losses during evacuation, as can be noted by the consistency of the $\mathrm{CO}_{2}$ yields (Table 2) recovered after combustion.

Atmospheric $\mathrm{CO}_{2}$ samples were measured to evaluate the ${ }^{14} \mathrm{C}$ levels of air at plant growth sites and in sample processing labs. $\mathrm{CO}_{2}$ was extracted from 2-L collection flasks of whole air. The collection flask was attached to an evacuated line to allow the air to flow through it at a rate set by a mass flow controller. Water was separated from the air gas mixture by freezing in a water trap, and $\mathrm{CO}_{2}$ was cryogenically removed. Once all of the air in the flask had been flowed through the system, the trapped $\mathrm{CO}_{2}$ was transferred to a Pyrex tube at a flame-off port and sealed.

The dry-ice graphite target (Table 2) was produced by placing a small amount of shaved dry ice into a culture tube, attaching it to the evacuated graphitization line, and subsequently following the usual steps of cryogenically trapping the $\mathrm{CO}_{2}$.

To evaluate ethanol and methanol $\mathrm{C}$ sources and whether phytoliths could potentially sorb them, quartz filters, $\mathrm{SiO}_{2}$ powder, and phytoliths themselves (used as substrates) were deliberatively spiked with these solvents (details below). Substrates plus solvents were combusted and graphitized as described earlier.

The ${ }^{14} \mathrm{C}$ dating of all samples was performed at the Keck-CCAMS Facility, USA, on graphite targets, pressed into aluminum target holders, mounted into the ion-source wheel and measured in the AMS (NEC 0.5MV 1.5SDH-2) compact system (Southon et al. 2004).

The uncertainties shown in Table 2 were calculated based on counting statistics and scatter in multiple measurements on each sample, along with propagated uncertainties from normalization to standards (OX-I) and secondary standards of the IAEA series from the ${ }^{14} \mathrm{C}$ intercomparison exercises (Le Clercq et al. 1998), background subtraction of size-dependent procedural blanks (based on measurements of ${ }^{14} \mathrm{C}$-free coal_-POC\#3 from Argonne Premium Coals, Vorres [1989]—and small OXI graphite targets; details are described below), and isotopic fractionation corrections provided by the on-line $\delta^{13} \mathrm{C}$ AMS values, following instrumental analysis described in Santos et al. (2007a,b).

\section{RESULTS AND DISCUSSION}

\section{Background Measurements}

Phytoliths are mainly composed of amorphous (noncrystalline) silicon dioxide $\left(\mathrm{SiO}_{2}\right)$ with several percent of water (Fraysse et al. 2006). To mimic the phytolith opal structure and to quantify the procedural background, we subjected $\mathrm{SiO}_{2}$ powder (Aldrich, -325 mesh) to the full phytolith extraction and AMS preparation procedure. We then compared the ${ }^{14} \mathrm{C}$ results obtained from these targets 
(spiked with dead coal or the modern OX-I standard) with targets of pure coal and OX-I, and with baked but otherwise untreated $\mathrm{SiO}_{2}$ (spiked with coal) to: a) establish the background variability; $b$ ) allow comparisons between the phytolith extraction and the AMS sample preparation blank; and c) determine sources of contamination in the phytolith extraction procedure. Coal samples were pretreated by conventional acid/base/acid washes, followed by combustion and graphitization.

Figure 1 shows background results for the nominally ${ }^{14} \mathrm{C}$-free blanks produced, i.e. pure coals, and $\mathrm{SiO}_{2}$ powder (phytolith-extracted as well as simply baked) spiked and non-spiked with coal. No statistical differences were observed between $\mathrm{SiO}_{2}$ powder (non-phytolith extracted, spiked with coal) and pure coal samples, indicating that our ${ }^{14} \mathrm{C}$ AMS target sample preparation blank (combustion, graphitization and graphite target pressing only) is low $(<0.3 \mu$ g modern $\mathrm{C})$. However, the $\mathrm{SiO}_{2}$ powder samples subjected to the full phytolith extraction procedure (as described above) showed a higher modern carbon contamination component (MC $\sim 3.0 \pm 1.5 \mu \mathrm{g}$ of modern $\mathrm{C}$; Figure 1). Similarly, an extra correction for $\sim 2.0 \pm 1.0 \mu \mathrm{g}$ of dead carbon (DC) was also required to bring the results for the $\mathrm{SiO}_{2}$ powder samples spiked with small amounts of OX-I (Table 2) into agreement with the results for larger OX-I aliquots. These corrections are about 10 times higher than the corrections necessary for our ${ }^{14} \mathrm{C}$ AMS target preparation alone (Santos et al. 2007a,b). Mass balance blank subtractions using these results have been applied to the phytolith data shown in Table 2. Uncertainties of $50 \%$ were assumed for both the MC and DC components based on the scatter in the blank data, and these uncertainties are reflected in the propagated errors.

We also tried to produce $\mathrm{CO}_{2}$ using previously combusted phytoliths as a starting sample material (Figure 2 and Table 2). However, the amount of $\mathrm{CO}_{2}$ produced was too small to be graphitized and measured, showing that the occluded $\mathrm{C}$ was efficiently extracted during the first combustion.

\section{Precision and Accuracy Tests on Soil Phytoliths}

Initial ${ }^{14} \mathrm{C}$ ages of the Kandara series $(433 \pm 20 \mathrm{yr}$ BP; Table 2$)$ were more reproducible than the results obtained from MSG70 samples (2707 $\pm 174 \mathrm{yr} \mathrm{BP}$; Table 2). However, the mean ${ }^{14} \mathrm{C}$ age measured for MSG70 was in the range (poorly constrained) of the expected ages $\left(335 \pm 90{ }^{14} \mathrm{C}\right.$ and $3820 \pm 85{ }^{14} \mathrm{C}$ ), while ${ }^{14} \mathrm{C}$ ages of the Kandara sample were slightly older than expected.

Kandara and MSG70 phytolith samples were then returned to CEREGE for further cleaning, since we believed that the older ${ }^{14} \mathrm{C}$ results were associated with an older organic matter $(\mathrm{OM})$ fraction attached to the sample surface due to some incomplete chemical oxidation. To remove OM from phytolith samples, they were rinsed again with equal amounts of $8 \% \mathrm{HClO}_{4}$ and $\mathrm{HNO}_{3}$ (step d, as described above). Indeed, the extra OM oxidation removed, respectively, $20 \%$ and $55 \%$ of the total $\mathrm{C}$ contents of the MSG70 and Kandara samples (percentage yield calculation based on the amount of $\mathrm{CO}_{2}$ recovered after combustion; Table 2).

The average ${ }^{14} \mathrm{C}$ age of the MSG70 sample did not change significantly after the post-OM cleaning, yielding an average age of $2563 \pm 85 \mathrm{yr}$ BP (Table 2). However, the results from Kandara phytoliths became unexpectedly older after this extra $\mathrm{OM}$ cleaning, and were statistically unchanged when 2 of the samples processed was prebaked at $500{ }^{\circ} \mathrm{C}$ rather than $160{ }^{\circ} \mathrm{C}$ before evacuation and sealing for combustion at $900{ }^{\circ} \mathrm{C}(2043 \pm 233 \mathrm{yr} \mathrm{BP}$; Table 2). Percentage yield calculations indicate that some occluded $\mathrm{C}$ was lost at this high prebake temperature $\left(500^{\circ} \mathrm{C}\right)$ due to leakage from the melted silica body. An even older ${ }^{14} \mathrm{C}$ result was obtained when the initial Kandara material (before the preOM cleaning) was acid washed with $\mathrm{HCl}$.

Although we successfully obtained reproducible ${ }^{14} \mathrm{C}$ results from phytolith carbon from both phytolith samples through multiple ${ }^{14} \mathrm{C}$ AMS measurements after this additional cleaning, the unex- 


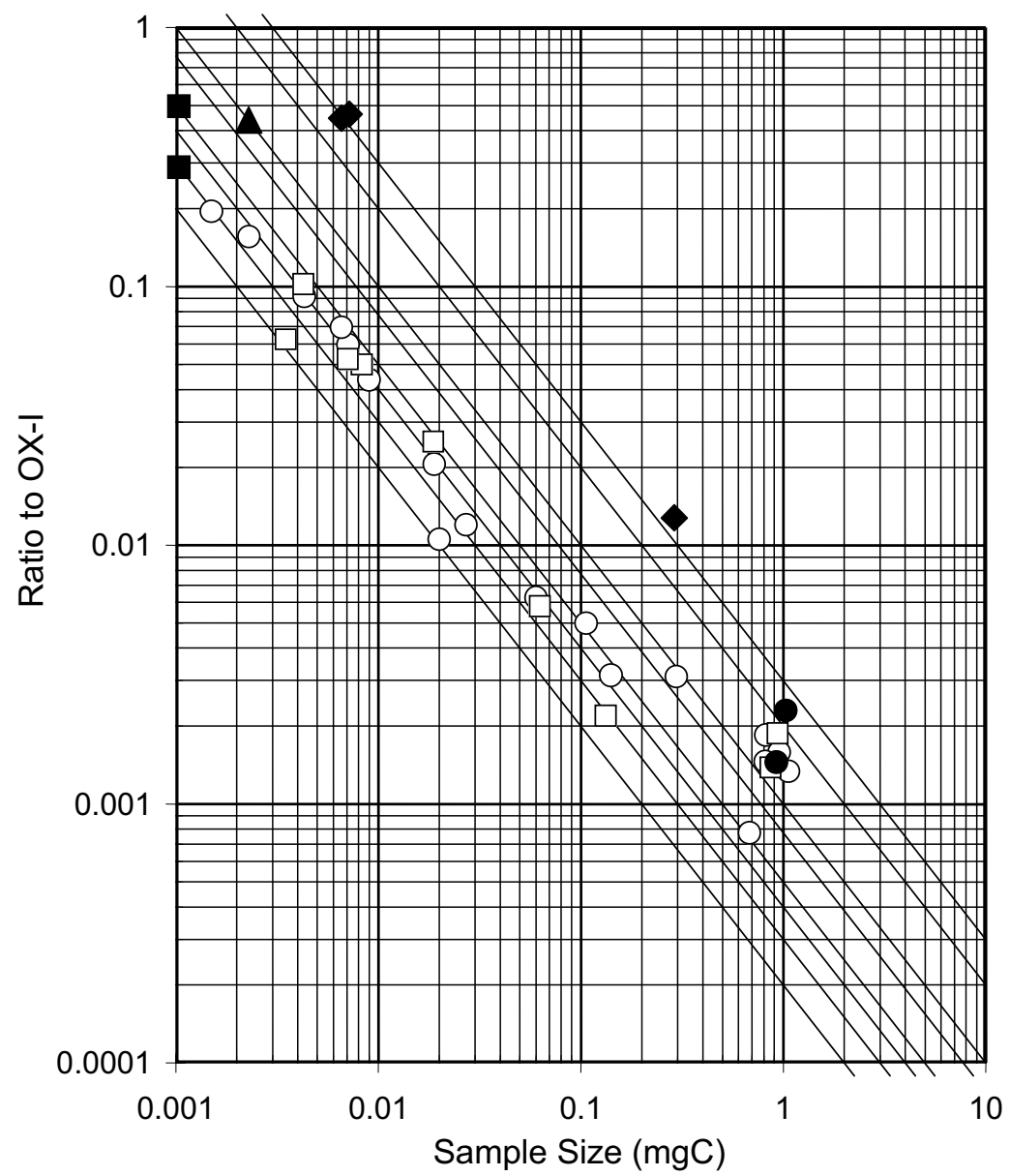

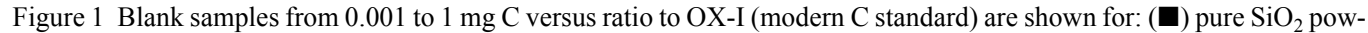
der subjected to the ${ }^{14} \mathrm{C}$ AMS sample preparation (Table 2; target \# UCIAMS37847 and 37848), (4) pure $\mathrm{SiO}_{2}$ powder exposed in the lab area for 7 consecutive days and subjected to the ${ }^{14} \mathrm{C}$ AMS sample preparation (UCIAMS48560); ( ) $\mathrm{SiO}_{2}$ powder submitted to phytolith extraction in addition to the ${ }^{14} \mathrm{C}$ AMS sample preparation (UCIAMS48561 and 48562 [nothing added] and 48622 [spiked with coal to increase sample size]); $(\bullet)$ melted phytolith (previously combusted at $900{ }^{\circ} \mathrm{C}$ ) and spiked with coal (UCIAMS37843 and 37844). The other sets of background samples, i.e. ( $\square$ ) pure coal and (O) $\mathrm{SiO}_{2}$ powder spiked with coal and subjected to the ${ }^{14} \mathrm{C}$ AMS sample preparation (non-phytolith extracted), are shown for comparison and to illustrate how $\mathrm{SiO}_{2}$ can effectively be used for background corrections when dealing with silica opal structures $\left({ }^{14} \mathrm{C}\right.$ results from these sets are not reproduced in Table 2). Note that the relationship of graphitized sample sizes (in $\mathrm{mg} \mathrm{C}$ ) to ${ }^{14} \mathrm{C}$ activity (in ratio to the modern $\mathrm{C}$ standard) is linear (when shown in a log-log plot) and, consequently the diagonal solid lines represent the effects of fixed amounts of modern carbon contamination from 0.2 to $3 \mu \mathrm{g} C$ (left to right).

pected ${ }^{14} \mathrm{C}$ age shift of the Kandara material (presumably related to the extra organic matter removal) triggered further investigations that will be addressed in the next section.

\section{Source of Contamination Assessment}

Several lab procedures to extract phytoliths from soil and plant matrices have been published for numerous applications in archaeology and environmental sciences. In some of these procedures, solvents (ethanol, methanol, or acetone) have been used as a final chemical step to remove bromides, to accelerate the drying process before storage, or even to store extracted material (Twiss et al. 1969; 

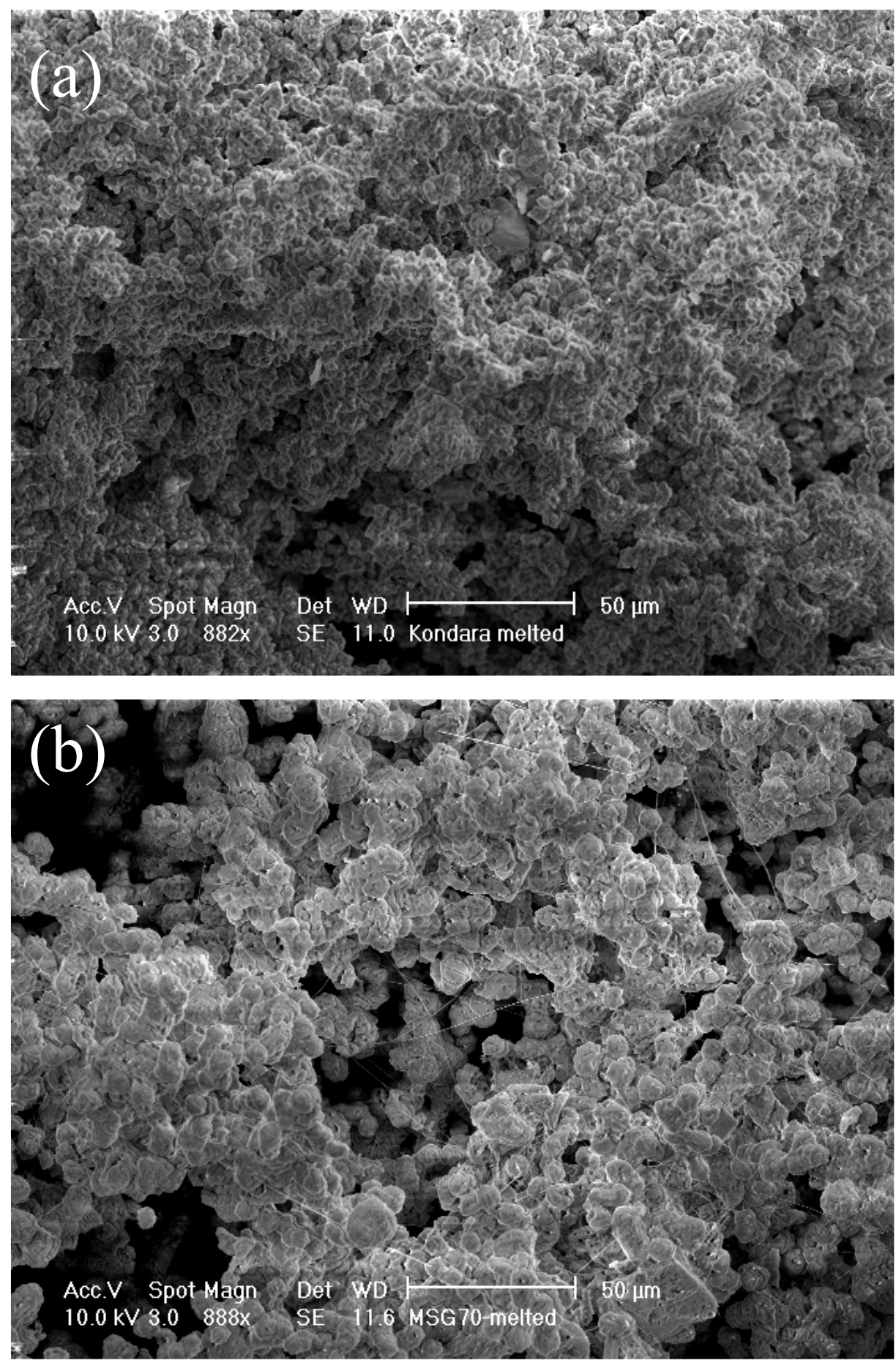

Figure 2 Scanning electron microscopy (SEM) pictures show how phytoliths were effectively melted after combustion at $900{ }^{\circ} \mathrm{C}$ : a) Kandara and b) MSG70. Pictures were taken at the Materials Characterization Facility, UCI, using a Schottky thermal field emission FEI/Philips XL-30 SEM with back-scattered electron detector. Scale is $50 \mu \mathrm{m}$. 
Geis 1973; Carbone 1977; Madella 1996; Madella et al. 1998; Parr 2002; Coil et al. 2003). The use of solvent should not be a problem if the focus of the study is morphology, phytolith production, or morphological classification schemes. However, chemical phytolith extractions for ${ }^{14} \mathrm{C}$ measurements should always avoid any source of extraneous carbon (Piperno 2006, 2009). In a different study, lipid extraction methods for diatom samples (silicate with similar structure to opal phytoliths) were evaluated with and without the use of solvents (Schlechtriem et al. 2003). Their findings suggested that carbon stable isotopic signatures were somehow altered when chloroform was used during extraction, which we speculate may have been due to strong adsorption of the solvent on silica and incomplete subsequent removal.

In our case, a few drops of ethanol from CEREGE were used to moisten the hydrophobic PTFE filters that received MSG70 and Kandara phytoliths densimetrically separated at CEREGE. Although the amount of ethanol used was extremely small, it raised concern since in the past we have seen solvent bonding to surfaces on quartz filters (Santos et al. 2007b). In the USA, ethanol is usually made from corn (i.e. contains contemporary levels of ${ }^{14} \mathrm{C}$ ), whereas methanol and acetone are usually ${ }^{14} \mathrm{C}$ free. Since the $\mathrm{C}$ source from the CEREGE ethanol was unknown, quartz filters and $\mathrm{SiO}_{2}$ were spiked with large amounts of this solvent and measured. The ${ }^{14} \mathrm{C}$ results compared with results from pure coal samples show that the ethanol was modern (Table 2), i.e. the ${ }^{14} \mathrm{C}$ background from quartz filters and $\mathrm{SiO}_{2}$ powder exposed to ethanol and then spiked with coal increased 20 and 60 times, respectively, compared with unexposed coal-spiked samples. Therefore, the ethanol used in the CEREGE phytolith filtration was not the reason for the Kandara age increase.

To further demonstrate that solvents can sorb to phytoliths (as expected due to their very large surface area and the strong absorptive properties of clean silica; Hatté et al. 2008) similar investigations were conducted directly on extracted phytolith samples. The ${ }^{14} \mathrm{C}$ age results were also consistent with the source of $\mathrm{C}$ in solvent spiking, with ${ }^{14} \mathrm{C}$-free methanol shifting the ${ }^{14} \mathrm{C}$ results to older values. The MSG70 that initially yielded ${ }^{14} \mathrm{C}$ age of $2707 \pm 174 \mathrm{yr} \mathrm{BP}(n=6)$ shifted to $3610 \pm 150 \mathrm{yr}$ $\mathrm{BP}$, while the MSG70-OM removed shifted from $2563 \pm 85(n=3)$ to $2670 \pm 140 \mathrm{yr}$ BP (Table 2). Note that phytolith samples after being spiked with solvent were subjected to the same AMS sample preparation procedure as previously, i.e. baking at $160{ }^{\circ} \mathrm{C}$ before sealing and combustion at $900{ }^{\circ} \mathrm{C}$. The baking may have helped to evaporate some of the solvent residue; however, it was clearly insufficient to remove all of it. Solvent-contaminant contributions can impact the ${ }^{14} \mathrm{C}$ results significantly, and cannot be properly quantified for background subtraction because the amount of sorbed solvent may be highly variable (as shown above). Although we did not obtain stable isotope $\delta^{13} \mathrm{C}$ measurements from the phytolith carbon contaminated with solvent, caution is advised when using solvents in phytolith extraction procedures even when it is only for stable isotope measurements.

The ${ }^{14} \mathrm{C}$ analyses of air samples (Table 2) showed that the laboratories involved in the sample processing were clean. The KCCAMS/UCI prep lab air is $98 \%$ modern (slightly lower than clean 2008 air, probably due to the presence of dry ice used during graphitization procedures), while the CEREGE lab is $104 \%$ modern (very close to 2008 air). A longer-term air contamination study was carried out by measuring $\mathrm{SiO}_{2}$ powder that was exposed to the KCCAMS/UCI prep lab environment for 7 consecutive days (note that as well as atmospheric $\mathrm{CO}_{2}$, this material would sorb any "old" non- $\mathrm{CO}_{2}$ gas contaminants that might affect the phytolith samples). A target with $0.0023 \mathrm{mg} \mathrm{C}$ was produced from $91.5 \mathrm{mg}$ of $\mathrm{SiO}_{2}$ powder, following the sample preparation described above (except baking it at $160{ }^{\circ} \mathrm{C}$ to avoid removing contaminants). Its ${ }^{14} \mathrm{C}$ value (UCIAMS48560, Table 2) does not indicate that the air in the lab is ${ }^{14} \mathrm{C}$-depleted enough to affect the ${ }^{14} \mathrm{C}$ results obtained for Kandara samples. 
In summary, no sources of old $\mathrm{C}$ contaminant that could have been added during the chemical extraction procedure were found.

\section{Accuracy Tests on Harvested Plants Phytoliths}

Since no evident sources of old $\mathrm{C}$ contaminant were found, we decided to measure ${ }^{14} \mathrm{C}$ in phytolith carbon from harvested plants (which are expected to reflect contemporary atmospheric ${ }^{14} \mathrm{C}$ levels). These samples were collected from rural areas (Table 1) and chemically processed in CEREGE and UW-Madison, using the protocol described above. Air samples from the US localities were also checked to rule out the possibility of any urban $\mathrm{CO}_{2}$ contamination. Samples from the bulk harvested plants were also processed and measured, showing that they are indeed modern, but the phytolith carbon extracted from these plants gave ages of several thousand years (Table 2). $\mathrm{The}^{\mathrm{SiO}} 2$ exposed to the full chemical extraction at CEREGE did pick up significant carbon contamination ( $\sim 3 \mu \mathrm{g}$ of modern $\mathrm{C}$ and $\sim 2 \mu \mathrm{g}$ of dead $\mathrm{C}$ ) from the chemicals or apparatus. However, this is far too little to explain the systematic age offset, and the phytolith results have been corrected for these blanks. The phytolith extraction protocol used on harvested plants did not involve filtration; therefore, no solvent entered into contact with samples. Furthermore, Pyrex beakers and glass vials were solely used. Consequently, polypropylene contamination from centrifuge tube inner surfaces cannot be blamed for the age shift to older values. In addition, since samples were fully processed in different labs, the age offset could not be attributed to possible lab contamination. These ${ }^{14} \mathrm{C}$ AMS age discrepancies thus suggest that the extraction procedure alone allows the preservation of an old $\mathrm{C}$ residue on phytolith samples, strongly resistant to oxidation and high temperatures. As mentioned earlier, 2 of the Kandara phytolith samples measured were prebaked at $500{ }^{\circ} \mathrm{C}$ in a furnace before they were vacuum sealed for combustion. The $\mathrm{C}$ occluded was partially lost by leakage as was demonstrated by the $\mathrm{CO}_{2}$ yield calculation, but the average ${ }^{14} \mathrm{C}$ result did not change (Table 2).

In ${ }^{14} \mathrm{C}$ dating, a mass-dependent fractionation effect determined from the measurement of $\delta^{13} \mathrm{C}$ values of the sample has to be taken into account to correct the final ${ }^{14} \mathrm{C}$ results. Piperno (2009) suggested that age errors of a few years could be introduced if not enough phytolith material is available for both ${ }^{14} \mathrm{C}$ AMS and stable isotope measurements, and estimated rather than measured $\delta^{13} \mathrm{C}$ values are used for the correction. However, the age offsets observed here cannot possibly be associated with isotopic fractionation, because: a) the age offset is far too large, and b) our AMS system measures $\delta^{13} \mathrm{C}$ on-line, so that we correct for any "machine" isotopic shifts as well as the natural and sample preparation fractionation combined.

\section{SUMMARY AND FUTURE WORK}

In this work, we demonstrated that it is possible to obtain reproducible ${ }^{14} \mathrm{C}$ results from phytolith carbon by multiple ${ }^{14} \mathrm{C}$ AMS measurements from graphite targets produced from large pools of phytoliths. The results obtained show $<1 \%$ precision. The $\mathrm{CO}_{2}$ yield from phytolith combustion was also very consistent when samples were prebaked at $160{ }^{\circ} \mathrm{C}$ overnight before evacuation and attached warm to the vacuum line to avoid "boiling" of the powder under vacuum. Tests using recombusted phytoliths show that the combustion yields are close to $100 \%$. In addition, $\mathrm{SiO}_{2}$ powder was successfully used for background assessment of both AMS target sample preparation and phytolith extraction procedures.

Although the extraction procedure seems robust and the ${ }^{14} \mathrm{C}$ dates on phytolith carbon samples were close to those expected (for MSG70 samples), the age of the only sample thought to be modern (Kandara sample) was unexpectedly old and was apparently biased by an unknown old $\mathrm{C}$ source. ${ }^{14} \mathrm{C}$ results from recent harvested plants from 3 locations were also inexplicably old, though bulk 
material from the same plants gave contemporary ${ }^{14} \mathrm{C}$ values. The labs involved in the phytolith extraction and AMS sample preparation were checked for potential sources of old carbon contaminants using $\mathrm{CO}_{2}$ extracted from lab air and $\mathrm{SiO}_{2}$ powder exposed to the lab environment; none were found. Some areas of extreme concern include: a) how can extraction procedures (without involving solvents) can affect the final results, and b) how can phytolith carbon be contaminated by any old C fractions?

As mentioned earlier, the only post-bomb ${ }^{14} \mathrm{C}$ result on phytolith carbon that we can find was published by Piperno and Becker (1996). No other published material from the last 2 decades is available showing ${ }^{14} \mathrm{C}$ results from phytolith carbon associated with "modern" vegetation that can help us to elucidate the ${ }^{14} \mathrm{C}$ age shifts to older results seen in this work.

In future work, we will evaluate other extraction protocols (Prior et al. 2005; Piperno 2006) as well as the one used in this study (Kelly et al. 1990), utilizing phytolith samples obtained from harvested plants grown within a FACE (Free-Air Carbon Dioxide Enrichment) experiment. In these experiments, controlled plots are exposed to enriched $\mathrm{CO}_{2}$ concentrations with known ${ }^{14} \mathrm{C}$ and $\delta^{13} \mathrm{C}$ values. We plan to extract phytoliths from living plants in both enriched and control plots and apply a coupled isotope signature approach (AMS ${ }^{14} \mathrm{C}$ and stable isotope $\delta^{13} \mathrm{C}$ ) to determine the sources of dead carbon in phytoliths.

\section{ACKNOWLEDGMENTS}

We thank Xaiomei Xu for assistance with the air samples, Elise Hinger for SEM pictures as well as literature searches, and Sue Trumbore for valuable discussions. The authors also wish to acknowledge the comments and suggestions of 2 reviewers, Christine Hatté and Tim Jull, as well as the managing editor, Mark McClure.

\section{REFERENCES}

Albert RM, Bamford MK, Cabanes D. 2006. Taphonomy of phytoliths and macroplants in different soils from Olduvai Gorge (Tanzania) and the application to PlioPleistocene palaeoanthropological samples. Quaternary International 148(1):78-94.

Blecker SW, McCulley RL, Chadwick OA, Kelly EF. 2006. Biologic cycling of silica across a grassland bioclimosequence. Global Biogeochemical Cycles 20: GB3023, doi:10.1029/2006GB002690.

Bremond L, Alexandre A, Peyron O, Guiot J. 2005a. Grass water stress estimated from phytoliths in West Africa. Journal of Biogeography 32(2):311-27.

Bremond L, Alexandre A, Hély C, Guiot J. 2005b. A phytolith index as a proxy of tree cover density in tropical areas: calibration with Leaf Area Index along a forest-savanna transect in southeastern Cameroon. Global and Planetary Change 45:277-93.

Bremond L, Alexandre A, Wooller MJ, Hély C, Williamson D, Schäfer PA, Majule A, Guiot J. 2008a. Phytolith indices as proxies of grass subfamilies on East African tropical mountains. Global Planetary Change 61(34):209-24.

Bremond L, Alexandre A, Peyron O, Guiot J. 2008b. Definition of grassland biomes from phytoliths in West Africa. Journal of Biogeography 35(11):2039-
48.

Carbone VA. 1977. Phytoliths as paleoecological indicators. Annals of the New York Academy of Sciences 288: 194-205.

Carter JA. 2009. Atmospheric carbon signatures in phytolith-occluded carbon. Quaternary International 193(1-2):20-9.

Coil J, Korstanje MA, Archer S, Hastorf CA. 2003. Laboratory goals and considerations for multiple microfossil extraction in archaeology. Journal of Archaeological Science 30(8):991-1008.

Crespin J, A Alexandre A, Sylvestre F, Sonzogni C, Paillès C, Garreta V. 2008. IR laser extraction technique applied to oxygen isotope analysis of small biogenic silica samples. Analytical Chemistry 80(7): 2372-8.

Elbaum R, Melamed-Bessudo C, Tuross N, Levy AA, Weiner S. 2009. New methods to isolate organic materials from silicified phytoliths reveal fragmented glycoproteins but no DNA. Quaternary International 193(1-2):11-9.

Fraysse F, Pokrovsky OL, Schott J, Meunier J-D. 2006. Surface properties, solubility and dissolution kinetics of phytoliths from bamboos of Reunion Island. Geochimica et Cosmochimica Acta 70(8):1939-51. 
Geis JW. 1973. Biogenic silica in selected species of deciduous angiosperms. Soil Science 116(2):113-30.

Hatté C, Hodgins G, Jull AJT, Bishop B, Tesson B. 2008. Marine chronology based on ${ }^{14} \mathrm{C}$ dating on diatoms proteins. Marine Chemistry 109(1-2):143-51.

Kelly EF. 1990. Method for extracting opal phytoliths from soil and plant material. Internal Report. Department of Agronomy, Colorado State University, Fort Collins.

Kelly E, Amundson R, Marino BD, Deniro M. 1991. Stable isotope ratios of carbon in phytoliths as a quantitative method of monitoring vegetation and climate change. Quaternary Research 35(2):222-33.

Le Clercq M, van der Plicht J, Gröning M. 1998. New ${ }^{14} \mathrm{C}$ Reference materials with activities of 15 and 50 pMC. Radiocarbon 40(1):295-7.

Lu HY, Wu NQ, Yang XD, Jiang H, Liu K, Liu TS. 2006. Phytoliths as quantitative indicators for the reconstruction of past environmental conditions in China. I: phytolith-based transfer functions. Quaternary Science Reviews 25(9-10):945-59.

Madella M. 1996. Phytolith analysis from the Indus Valley site of Kot Kiji, Sing, Pakistan. In: Sinclair AGM, Slater EA, Gowlett JAJ, editors. Archaeological Sciences 1995. Oxford: Oxbow Monographs. p 312-20.

Madella M, Powers-Jones AH, Jones MK. 1998. A simple method of extraction of opal phytoliths from sediments using a non-toxic heavy liquid. Journal of Archaeological Science 25(8):801-3.

McClaran MP, Umlauf M. 2000. Desert grassland dynamics estimated from carbon isotopes in grass phytoliths and soil organic matter. Journal of Vegetation Science 11(1):71-6.

Meunier JD, Colin F, Alarcon C. 1999. Biogenic silica storage in soils. Geology 27(9):835-8.

Mulholland SC, Prior CA. 1993. AMS radiocarbon dating of phytoliths. In: Pearsall DM, Piperno DR, editors. Current Research in Phytolith Analysis: Applications in Archaeology and Paleoecology. MASCA Research Papers in Science and Archaeology 10. Philadelphia: University Museum of Archaeology and Anthropology, University of Pennsylvania. p 21-3

Ouar S. 1998. Caractéristation spatio-temporelle du couvert vegetal des zones à Mascareignite de l'Ile de La Réunion [PhD dissertation]. Université Aix-Marseille III. $156 \mathrm{p}$.

Parr JF. 2002. A comparison of heavy liquid floatation and microwave digestion techniques for the extraction of fossil phytoliths from sediments. Review of Paleobotany and Palynology 120(3-4):315-36.

Piperno DR. 2006. Phytoliths: A Comprehensive Guide for Archaeologists and Paleoecologists. New York: AltaMira Press. 238 p.

Piperno DR. 2009. Identifying crop plants with phytoliths (and starch grains) in Central and South America: a review and update of evidence. Quaternary International 193(1-2):146-59.
Piperno DR, Becker P. 1996. Vegetational history of a site in the central Amazon Basin derived from phytolith and charcoal records from natural soils. Quaternary Research 45(2):202-9.

Piperno DR, Pearsall DM. 1993. AMS radiocarbon dating of phytoliths. In: Pearsall DM, Piperno DR, editors. Current Research in Phytolith Analysis: Applications in Archaeology and Paleoecology. MASCA Research Papers in Science and Archaeology 10. Philadelphia: University Museum of Archaeology and Anthropology, University of Pennsylvania. p 9-18.

Piperno DR, Stothert KE. 2003. Phytolith evidence for early Holocene Cucurbita domestication in southwest Ecuador. Science 299(5609):1054-7.

Pironon J, Meunier JD, Alexandre A, Mathieu R, Mansuy L, Grosjean A, Jardé E. 2001. Individual characterization of phytoliths: experimental approach and consequences on paleoenvironment understanding. In: Meunier JD, Colin F, editors. Phytoliths: Applications in Earth Sciences and Human History. Lisse: A.A. Balkema Publishers. p 329-41.

Prasad V, Strömberg CAE, Alimohammadian H, Sahni A. 2005. Dinosaur coprolites and the early evolution of grasses and grazers. Science 310(5751):1177-80.

Prior CA, Carter JA, Rieser U. 2005. Are phytolith radiocarbon dates reliable? Poster presented at the 10th International Conference on Accelerator Mass Spectrometry, Berkeley, USA, September 2005.

Rieser U, Carter JA, Prior CA. 2007. Phytoliths: a chronometer for the late Quaternary. Poster presented at the INQUA 2007 Conference, Cairns, Australia, July/ August 2007.

Sangster AG, Hodson MJ, Ling LEC. 2009. Biomineralisation/environment interactions in conifers: illustrated by hemlock, Tsuga canadensis (L.) Carr. Quaternary International 193(1-2):3-10.

Santos GM, Southon JR, Druffel-Rodriguez KC, Griffin S, Mazon M. 2004. Magnesium perchlorate as an alternative water trap in AMS graphite sample preparation: a report on sample preparation at KCCAMS at the University of California, Irvine. Radiocarbon 46(1): 165-73.

Santos GM, Southon JR, Griffin S, Beaupre SR, Druffel ERM. 2007a. Ultra small-mass AMS ${ }^{14} \mathrm{C}$ sample preparation and analysis at the KCCAMS/UCI Facility. Nuclear Instruments and Methods in Physics Research B 259(1):293-302.

Santos GM, Moore SB, Southon JR, Griffin S, Hinger E, Zhang D. 2007b. AMS ${ }^{14} \mathrm{C}$ sample preparation at the KCCAMS/UCI Facility: status report and performance of small samples. Radiocarbon 49(2):255-69.

Schlechtriem C, Focken U, Becker K. 2003. Effect of different lipid extraction methods on $\delta^{13} \mathrm{C}$ of lipid and lipid-free fractions of fish and different fish feeds. Isotopes in Environmental and Health Studies 39(2):13540.

Smith FA, Anderson KB. 2001. Characterization of or- 
ganic compounds in phytoliths: improving the resolving power of phytolith $\delta^{13} \mathrm{C}$ as a tool for paleoecological reconstruction of $\mathrm{C} 3$ and $\mathrm{C} 4$ grasses. In: Meunier JD, Colin F, editors. Phytoliths: Applications in Earth Sciences and Human History. Lisse: A.A. Balkema Publishers. p 317-27.

Smith FA, White JWC. 2004. Modern calibration of phytolith carbon isotope signatures for $\mathrm{C}_{3} / \mathrm{C}_{4}$ paleograssland reconstruction. Palaeogeography, Palaeoclimatology, Palaeoecology 207(3-4):277-304.

Southon JR, Santos GM, Druffel-Rodriguez KC, Druffel E, Trumbore S, Xu X, Griffin S, Ali S, Mazon M. 2004. The Keck Carbon Cycle AMS laboratory, University of California, Irvine: initial operation and a background surprise. Radiocarbon 46(1):41-9.

Stuiver M, Polach H. 1977. Discussion: reporting of ${ }^{14} \mathrm{C}$ data. Radiocarbon 19(3):355-63.

Twiss PC, Sues E, Smith RM. 1969. Morphological clas- sification of grass phytoliths. Soil Science Society of America Proceedings 33:109-15.

Vorres KS. 1989. Users Handbook for the Argonne Premium Coal Sample Program. ANL/PCSP-89/1, October 1989. Available at http://www.anl.gov/PCS/report/part1.html.

Webb EA, Longstaffe FJ. 2002. Climatic influences on the oxygen isotopic composition of biogenic silica in prairie grass. Geochimica et Cosmochimica Acta 66(11):1891-904.

Wilding LP, Brown RE, Holowaychuk N. 1967. Accessibility and properties of occluded carbon in biogenic opal. Soil Science 103:56-61.

Zhao Z, Piperno DR. 2000. Late Pleistocene/Holocene environments in the middle Yangtze River Valley, China and rice (Oryza sativa L.) domestication: the phytolith evidence. Geoarchaeology 15(2):203-22. 